\title{
THE IMPACTS OF GOVERNMENT R\&D EXPENDITURE ON INNOVATION IN CHINESE PROVINCES: WHAT'S THE ROLE OF CORRUPTION
}

\author{
Xiao-Bo Zhou ${ }^{1}$, Wei Wei ${ }^{2}$, Chyi-Lu Jang ${ }^{3}$, Chun-Ping Chang ${ }^{4}$ \\ ${ }^{1}$ School of Economics, Zhengzhou University of Aeronautics, Zhengzhou, China. \\ Email: xiaobo@gmail.com \\ ${ }^{2}$ School of Economics and Finance, Xi'an Jiaotong University, Shaanxi, China. \\ Email: weiwei@xaut.edu.cn \\ ${ }^{3}$ Department of Political Economy, National Sun Yat-sen University, Kaohsiung, Taiwan. \\ Email: cjang@mail.nsysu.edu.tw \\ ${ }^{4}$ Shih Chien University at Kaohsiung, Kaohsiung, Taiwan. Email: cpchang@g2.usc.edu.tw
}

\begin{abstract}
We investigate the moderating role of corruption on the effect of government research and development (R\&D) expenditure on enterprise innovation in China, using annual data from 2002 to 2013 in a panel of 30 provinces. Our findings show that R\&D expenditure does not influence the number of patent applications, but it does influence the number of patents granted. When considering official corruption, the interaction term of R\&D expenditure and corruption has a statistically significantly positive effect on the numbers of patent applications and patents granted, with corruption having significantly positive effects on the ratio of the number of patents granted to the number of patent applications.
\end{abstract}

Keywords: Research E development; Corruption; Innovation; Panel data.

JEL Classifications: C23; 031; D73; H5.

Article history:

Received : September 10, 2018

Revised : : December 11, 2018

Accepted : December 11, 2018

Available online : January 30, 2019

https://doi.org/10.21098/bemp.v21i3.977 


\section{INTRODUCTION}

The dynamic mechanism of innovation has drawn the attention of many economists since Schumpeter (1934) noted the importance of innovation's effect on economic growth. Nelson (1971) and Nelson and Winter (1982) argue that innovation is commonly considered a public good while being usually combined with positive externality (Delong and Lawrence, 1991). However, given that innovation's positive externality can lead to market failure, especially if an innovation project's positive benefits to society are unable to cover the firm's private costs, one outcome is that the project will not be implemented and, thus, the volume of innovations does not meet the socially desirable target. To solve the problem of positive externality, Cropper and Oates (1992) argue that public expenditure is the most suitable method after comparing taxes, public expenditures, making markets, and establishing property rights and regulations, because it allows for subsidies to equal the marginal external benefit of positive externality, thus resolving a market supply shortage.

Many studies analyze the relation between government research and development $(R \& D)$ expenditure and innovation, but there are wide differences between their empirical results (Dimos and Pugh, 2016). Some scholars contend that R\&D expenditures are complementary to financing a firm's R\&D spending (Bronzini and Piselli, 2016) while others perceive R\&D expenditures crowding out private R\&D spending (Boeing, 2016; David, Hall, and Toole, 2000). Vicente, Borrego, Forcadell, and Galan (2014) believe that these disparities mainly arise due to different methodologies, sample countries, and variables. Most research studies thus commonly neglect the role of institutional quality when investigating the impact of R\&D on innovation, which is a key focus of this paper.

According to rent-seeking theory, when government corruption is high, a large number of enterprises of low innovation ability could receive R\&D subsidies through bribery. These enterprises do not have enough innovative achievements to apply for patents, so the growth of $R \& D$ expenditure cannot promote the corresponding growth of enterprise patent applications. On the contrary, when the degree of government corruption is low, enterprises with low innovation ability have less chance of obtaining R\&D projects or R\&D funding support through bribery. R\&D subsidies are more likely to be given to enterprises or research institutes with high innovation ability and the amount of patent applications of enterprises will increase accordingly (Krueger, 1974; Fey, 2008; Gao, 2011).

Unlike traditional work, which focuses only on the link between R\&D expenditures and innovation, as well as that between corruption and innovation separately, we concentrate our attention on merging these variables. Our contribution can be interpreted as follows. We employ a panel system generalized method of moments (GMM) method and subject it to data on 30 Chinese provinces (including administered municipalities). This paper develops a fundamental model for analyzing how $R \& D$ expenditure affects enterprise innovations in China when exposed to corruption. In our analysis, domestic innovation is measured by the number of patent applications accepted (NPA), the number of patents granted (NPG), and the ratio of the number of patents granted to the number of patent applications (RGA) over the period 2002 to 2013. We then carry out robustness tests where the full samples are split into eastern, central, and western regions of 
China. These regions vary considerably in their economic and social development. As far as we know, ours is the first study to investigate the relationship between R\&D expenditures, corruption, and innovative activity.

Although the previous literature recognizes that corruption can dramatically affect firm behavior (Uhlenbruck, Rodriguez, Doh, and Eden, 2006), we note that the actual effect of corruption on innovation is less understood in earlier works, since studies report surprising disparity over corruption's influence on domestic innovation. For instance, scholars argue that corruption can increase transaction costs and risk for entrepreneurs, which can negatively influence innovation. Anokhin and Schulze (2009) argue that in the face of high corruption, controlling corruption can exert a greater impact on innovative activity. Specifically, RoseAckerman (2001) provides persuasive arguments on how the control of corruption links to the development of "institutionalized trust," which is instrumental in creating innovation, and also results in high levels of value-added economic activity in innovation investment.

Baker, Peli, Knouf, and Kanwisher (2005) and Rodriguez, Siegel, Hillman, and Eden (2006) suggest that corruption has implications for rewards from innovation. Similarly, corruption negatively influences a firm's growth, as, for instance, in the cases of Uganda and Central and Eastern European countries (see, Fisman and Svensson, 2007; and De Rosa, Gooroochurn and Gorg, 2010). ${ }^{5}$ Finally, corruption can hurt an enterprise's innovation because it can lead to the distortion of resource allocation (Baumol, 1990; Acemoglu and Verdier, 1998).

Given the argument that corruption spurs innovation, Murphy, Shleifer, and Vishny (1991) suggest that officials have monopoly power over the demand for bribes, though such public rent-seeking activities commonly shock innovators due to cash constraint. ${ }^{6}$ Furthermore, scholars have argued that well organized corruption networks positively influence innovative performance (Blackburn and Forgues-Puccio, 2009; Goedhuys, Mohnen, and Taha, 2016). ${ }^{7}$ According to these views, bribery appears to help overcome government ineffectiveness thus impeding efficient innovative activities (Williams, Martinez-Perez, and Kedir, 2016). Compared to the growing research documenting that corruption and innovation are negatively related, we offer some in-depth arguments.

China's economy has enjoyed remarkable economic growth rates of approximately $10 \%$ per year in the past few decades and R\&D funds in the country have grown at around 20\% per annum (Guo, Guo, and Jiang, 2016; Shi and Rao, 2010). However, the innovation level is low compared to the rapidly increasing economy and R\&D funds, mainly manifested by the small contribution of productivity to economic growth. How is R\&D expenditure, corruption, and innovation related? What is the role of corruption in this relation? These are the questions we answer. Our empirical results have strong policy implications for $\mathrm{R} \& \mathrm{D}$ expenditure, anticorruption, and government efficiency in China.

\footnotetext{
5 See also Waldemar (2012) and Amir and Burr (2015).

6 Similarly, bribery can help enterprises avoid red tape, lower the risks of administrative intervention to enterprise innovation, and reduce credit discrimination during the financing process (Qian and Xu, 1998; Yeh, Shu, and Chiu, 2013).

7 Well-organized networks mean strong coordination among bureaucrats.
} 
To sum up, we investigate the moderating role of corruption on the effect of $R \& D$ expenditure on enterprise innovation in China using the panel system GMM method. The method is employed on a dataset consisting of 30 Chinese provinces over the period 2002 to 2013. The relation between R\&D expenditure and enterprise innovation will be thoroughly scrutinized while considering the influence of corruption.

\section{LITERATURE REVIEW}

Over the past several decades, R\&D expenditure and institution quality have been the two most important factors determining the level of enterprise innovation. For example, several studies have shown that, given information asymmetry between capitalists and entrepreneurs, R\&D expenditure can expropriate innovative ideas via financial tunneling from the investee (Dushnitsky and Lenox, 2006). In other words, these studies find that government expenditure, aside from improving innovation, contributes to the positive externality of innovation, consistent with Griliches (1986). However, these findings are quite different from those of David et al. (2000), who find that the effect of R\&D expenditure on an enterprise's innovation is unclear, owing to government expenditure having a crowding-out effect on private $R \& D$ expenditure.

Several studies investigate the relationship between government and private $R \& D$ expenditures. The literature argues that $R \& D$ expenditure mainly plays a complementary role when compared to private R\&D (Diamond, 1999). Other papers, however, critically note that $R \& D$ expenditure can crowd out private $R \& D$ expenditure (Wallsten, 2000). Accordingly, though R\&D expenditure is a critical input for enterprise innovation, the empirical results are mixed, as in earlier arguments, given that most findings present methodological differences.

Recent papers investigate the role of $R \& D$ subsidies from the perspective of their differences. Le and Jaffe (2017), for example, consider research from the perspective of the innovation level of subsidiary objects and find that R\&D subsidies are important to innovation. Hence, Cin et al. (2017) and Choi and Lee (2017), among others, show that R\&D subsidies positively influence R\&D expenditure and small business productivity from the perspective of enterprise scale. From the perspective of absorptive capacity, Guisado-González et al. (2018) find that outgoing spillover effects of R\&D subsidies depend on the absorptive capacity of cooperative partners.

The literature on how institution quality affects enterprise innovation is also controversial. From the viewpoint that corruption is the lubricant of enterprise innovation, Leff (1964) believes that corruption not only efficiently reduces government intervention in business environments, but also provides an advantageous motivation for enterprise innovation in developing countries. Scholars, hence, argue that corruption provides an institutional arrangement of a fee-based service (Acemoglu and Verdier, 1998). ${ }^{8}$ Indeed, the bribe relationship

8 Corruption serves as speed money, which then increases efficiency by expediting the decisionmaking process (Leff, 1964). 
between enterprises and government acts as an important credit mechanism from the perspective of innovative activities and easing the financial restraint of enterprises under asymmetric information (Yeh et al., 2013).

The literature presents alternative arguments too. Baumol (1990), for instance, discusses the obstruction of corruption on enterprise innovation. He notes that, once the benefits of enterprises from a nonproductive activity such as bribery become greater than those from productive activity innovation, the enterprises may invest more resources into rent-seeking while reducing R\&D investments. Similar evidence from Indian data have been found by Waldemar (2012). Similarly, Murphy et al. (1991) lament that corruption leads to the distortion of the allocation of entrepreneurial talents, which can hurt enterprises' innovation ability (Tanzi, 1998; Ahlin and Bose, 2007). Anokhin and Schulze (2009) show that the effect of corruption on innovative action exhibits the terms of a curvilinear relationship and outline both negative and positive relationships between the control of corruption and innovative activities among their sample countries. ${ }^{9}$

Dreher and Gassebner (2013) argue that corruption has a positive impact on firm innovation via reducing uncertainty in the decision-making process and by providing a way to overcome bureaucratic obstacles. Dirienzo and Das (2014) discover that corruption significantly harms innovation activities; Paunov (2016) documents the impacts of corruption on smaller and larger firms' adoption of quality certification and patents in 48 developing and emerging countries. This study shows evidence that corruption reduces the likelihood of firms obtaining quality certificates, particularly for smaller firms.

Several works also investigate the relationship between institution quality and R\&D expenditure. Shleifer and Vishny (1994), for example, investigate the privatization of state firms and point out that government subsidies for enterprises are used not only in strategies to create rent but also for the purpose of managerial bribes. In addition, Li, Meng, Wang, and Zhou (2008) show that the role of the Communist Party of China in the operation of private enterprise is to construct political relations in place of a market mechanism. Enterprises can build up political relations by rent seeking and then obtaining scarce resources during their startup phase (Krueger, 1974; Glaeser and Saks, 2006).

Some studies have also investigated the relationship between R\&D expenditure and innovation in China. Among these, that of Shi and Rao (2010) points out the contradiction between high R\&D input and low innovation output in China, attributing this strange phenomenon to the problems of Chinese research culture, in which most researchers spend too much time building political connections and not enough time conducting academic research. Given that corruption can reduce government intervention for these enterprises, the analysis framework must account for institution quality to determine how R\&D expenditure influences enterprise innovation. The resultant research finding is worthwhile as it seeks to extend our knowledge of corruption and innovation in emerging countries.

9 This is similar to Rose-Ackerman (2001), who suggests that institutional trust could rise slowly in response to improvements in the control of corruption. 


\section{EMPIRICAL FRAMEWORK, METHODS, AND DATA}

A. Econometric models

To investigate whether corruption influences the effect of $R \& D$ expenditure on enterprise innovation, we first propose the following empirical framework:

$$
I N N_{i t}=\alpha I N N_{i t-1}+\rho G R D_{i t}+X_{i t} \phi^{\prime}+\mu_{i}+\eta_{t}+\varepsilon_{i t}
$$

where INN proxies for the innovation variable, GRD is R\&D expenditure, and $X$ stands for control variables that can influence enterprise innovation. We consider economic development, foreign direct investment, foreign trade openness, and regional dummy variables, including the eastern, central, and western regions. In Equation (1), $\mu_{i}$ captures individual effect, $\eta_{t}$ captures time-scale effect, $\varepsilon_{i t}$ is the estimated residual, with $t=1, \ldots, T$ periods and $i=1, \ldots N$ panel members.

The coefficient of GRD in Equation (1) captures the effects of R\&D expenditure on enterprise innovation. However, one drawback is that, once the initial level of the explained variable is correlated with an error term, then using ordinary least squares estimator could lead to bias estimates. To solve such a problem, we use the dynamic panel GMM model developed by Arellano and Bond (1991), Arellano and Bover (1995), and Blundell and Bond (1998).

Equation (1) is first differenced such that country-specific effects are eliminated:

$$
\Delta I N N_{i t}=\alpha \Delta I N N_{i t-1}+\rho \Delta G R D_{i t}+\Delta X_{i t} \phi^{\prime}+\eta_{t}-\eta_{t-1}+\Delta \varepsilon_{i t}
$$

where $\Delta$ denotes the first difference. We thus propose a system GMM estimator that stacks level and difference equations. The lagged levels are used as instruments for the first-differenced variables and the lagged first difference of the series as instruments for the level variables.

According to our earlier interpretations, we note the effect of R\&D expenditure on enterprise innovation could depend on the level of corruption (COR). Furthermore, we extend Equations (1) and (2) and evaluate the effect of GRD and its interaction effects with COR on INN. Hence, we estimate the following model:

$$
\begin{aligned}
\Delta I N N_{i t}= & \alpha \Delta I N N_{i t-1}+\rho \Delta G R D_{i t}+\beta \Delta C O R_{i t}+\lambda \Delta\left(G R D_{i t} * C O R_{i t}\right)+ \\
& \Delta X_{i t} \phi^{\prime}+\left(\eta_{t}-\eta_{t-1}\right)+\Delta \varepsilon_{i t}
\end{aligned}
$$

\section{B. Data}

The empirical test is conducted on annual data for the period 2002 to 2013 in a panel of 30 provinces in China. The specific provinces are shown as Figures 1 to 4. 


\section{Figure 1. Total NPA in China}

This figure shows the number of patent applications (NPA) of 30 provinces in China (2002-2013).

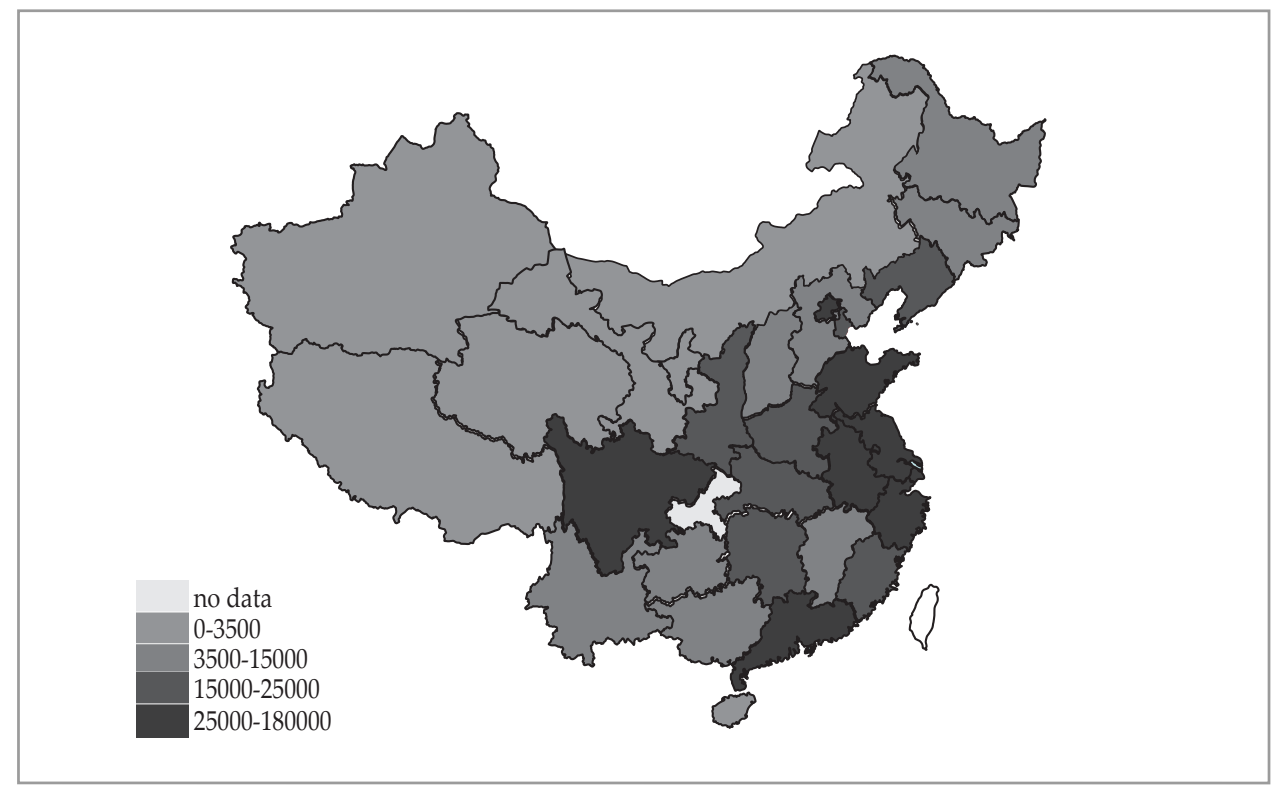

Figure 2. Total NPG in China

This figure shows the number of patents granted (NPG) of 30 provinces in China (2002-2013).

no data

0-2000

2000-7500

7500-15000

15000-90000

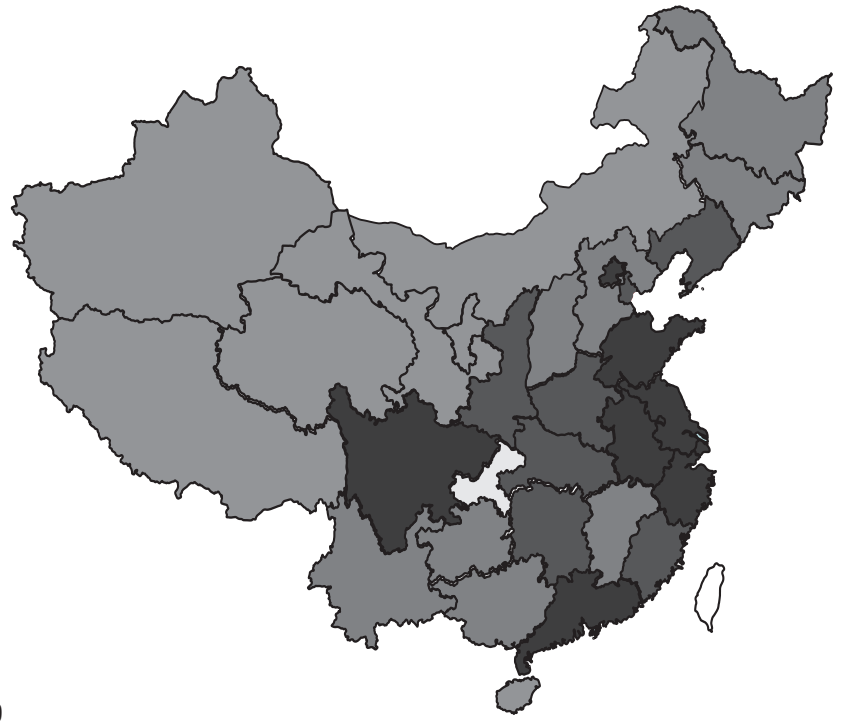


Figure 3. NPA in 2002 and 2013

This figure shows the number of patent applications (NPA) of 30 provinces in China in 2002 and 2013.

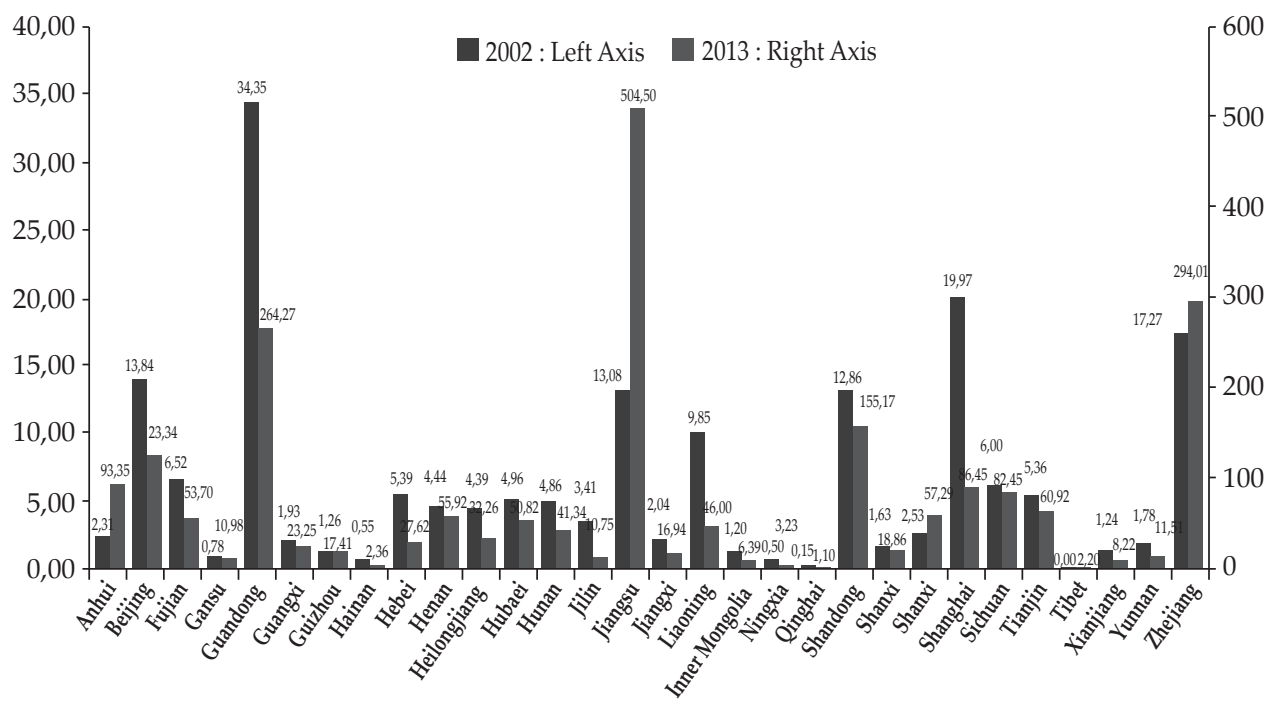

Figure 4. NPG in 2002 and 2013

This figure shows the number of patents granted (NPG) of 30 provinces in China in 2002 and 2013.

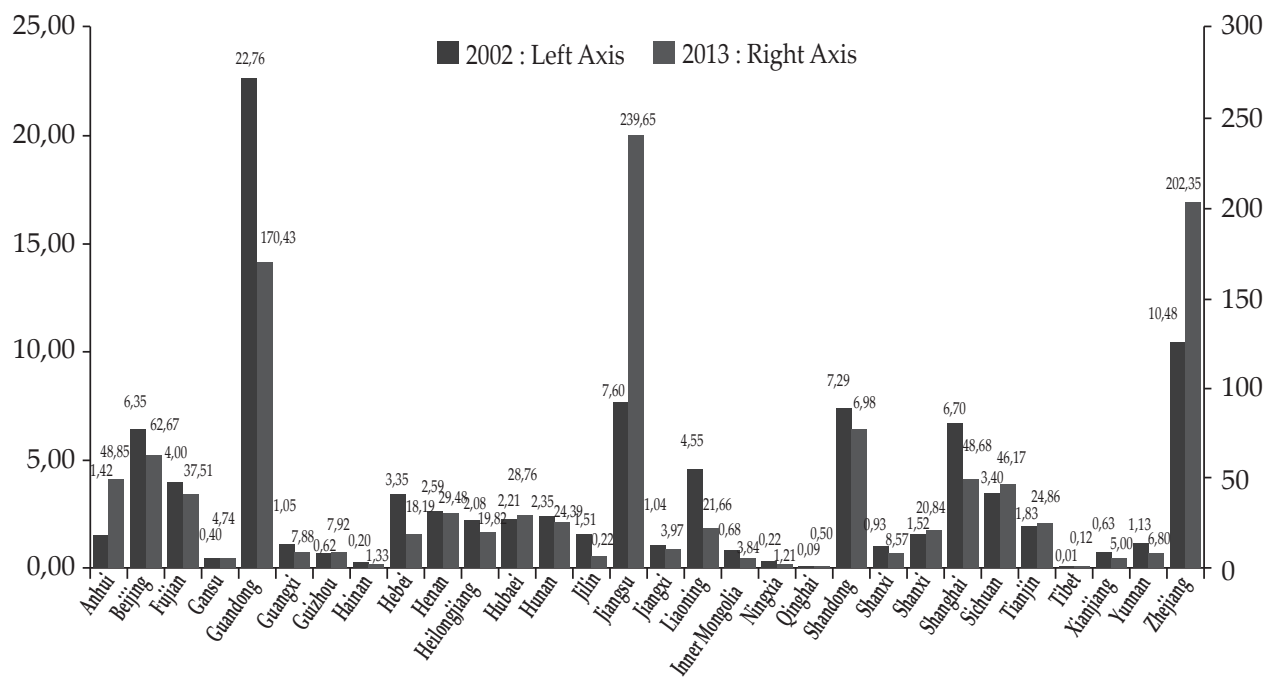




\section{B1. Dependent variables: Measurements of innovation}

We provide several definitions of innovation. Domestic innovative activity is proxied by the number of patent applications (NPA) filed by residents and nonresidents. Several studies define this as the innovation output variable (Hall and Lerner, 2010; Barbosa et al., 2014). In robustness tests, we consider two alternative measures of innovation. First, the literature has employed the number of patents granted (NPG) to reflect different dimensions of enterprise innovation (Desyllas and Hughes, 2010). We, therefore, also use NPG. Second, following Hirshleifer et al. (2012), we calculate the ratio of the number of patents granted to the number of patent applications, commonly recognized as the NPA-NPG ratio (RGA). The values for both NPA and NPG are taken from the China Statistical Yearbook.

As can be seen, both NPA and NPG are mainly concentrated in the eastern and central regions, which encompass the more developed areas of China. The provinces with higher NPA values include Beijing, Shanghai, Jiangsu, Zhejiang, Guangdong, and Shandong. Anhui also has a higher NPA value because there are more universities and research organizations there, which provides strong support for enterprise innovation ability. In the western region, we find no clear enterprise innovative activity, except in Sichuan, which has higher NPA and NPG values than the other areas. Furthermore, Anhui and Hebei are interesting because Anhui has a large NPA value but a lower NPG value, which is the opposite of Hebei. Figures 3 and 4 display the changes in enterprise innovation levels for each province between 2002 and 2013. We again find that the NPA and NPG values are higher in both the eastern and central regions compared to the western region.

\section{B2. Independent variables}

We next introduce several independent variables that impact innovation.

Government R\&D expenditure (GRD): Economists believe that GRD is an important way to solve the problem of market failure during the process of enterprise innovation. By comparison, enterprises that receive R\&D subsidies can cut their marginal cost of innovation and carry out more innovation activities. On the other hand, higher profits from innovation spillover effects arise because government expenditures not only improve innovation but also contribute to its positive externality (Ueda, 2004). Therefore, we argue that R\&D expenditure plays a critical role in encouraging enterprise innovation in China. R\&D expenditure data is obtained from the China Statistical Yearbook.

Government corruption (COR): Estimation of the extent of corruption for Chinese provinces is challenging. In this regard, we follow Dong and Torgler (2013), by considering the number of registered cases of corruption per 100,000 people in a province as a proxy for the degree/extent of corruption. This paper thus uses COR as the key explanatory variable and the data are collected from the Procuratorial Yearbook of China. We summarize all corruption cases in every province as shown in Figures 5 and 6. According to Figure 5, corruption cases are concentrated in the eastern and central regions, which is consistent with the regional distribution of the number of enterprise patent applications. However, Qinghai has more corruption cases in the western region, which could be due to the rich natural resources there. Hence, in Figure 6, we find that the corruption level has not obviously dropped from 2002 to 2013. 


\section{Figure 5. Total COR in China}

This figure shows the average of government corruption (COR) of 30 provinces in China (2002-2013). Government corruption is the number of registered cases of corruption per 100,000 people.

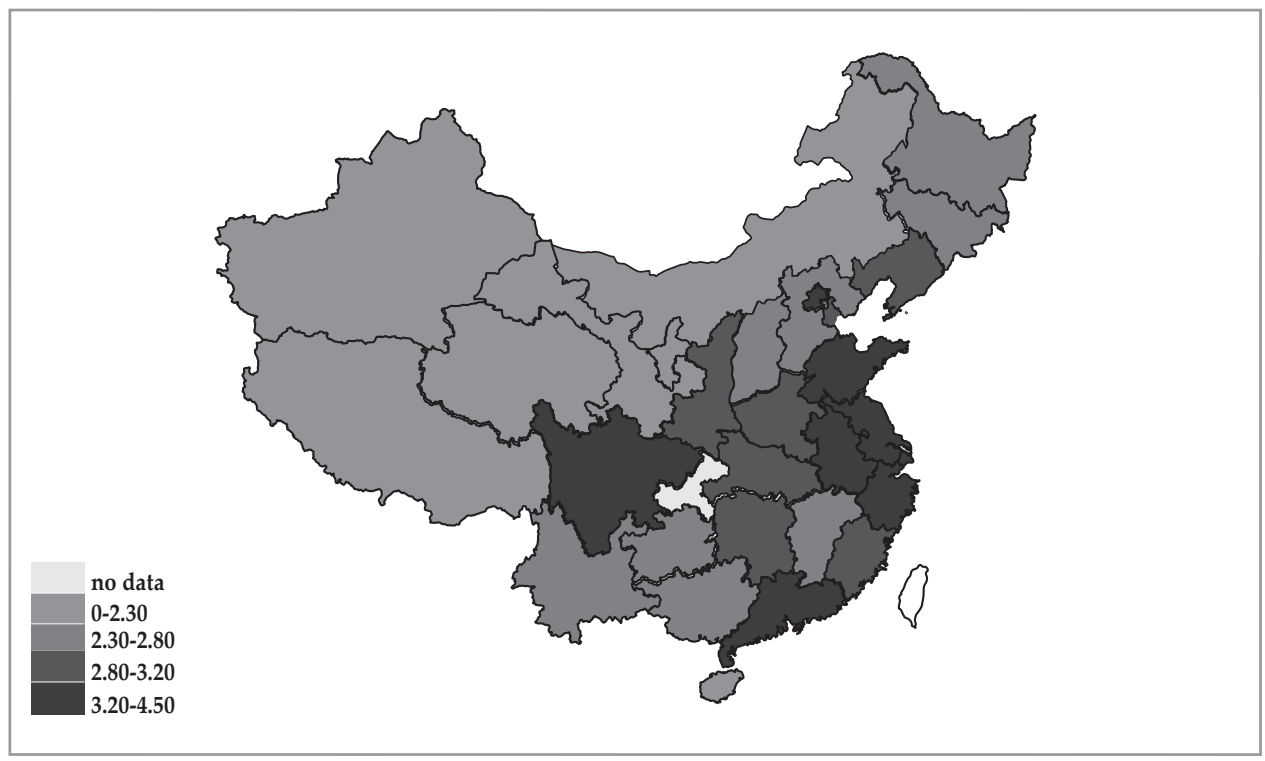

Figure 6. COR in 2002 and 2013

This figure shows the number of government corruption (COR) of 30 provinces in China in 2002 and 2013. Government corruption is the number of registered cases of corruption per 100,000 people.

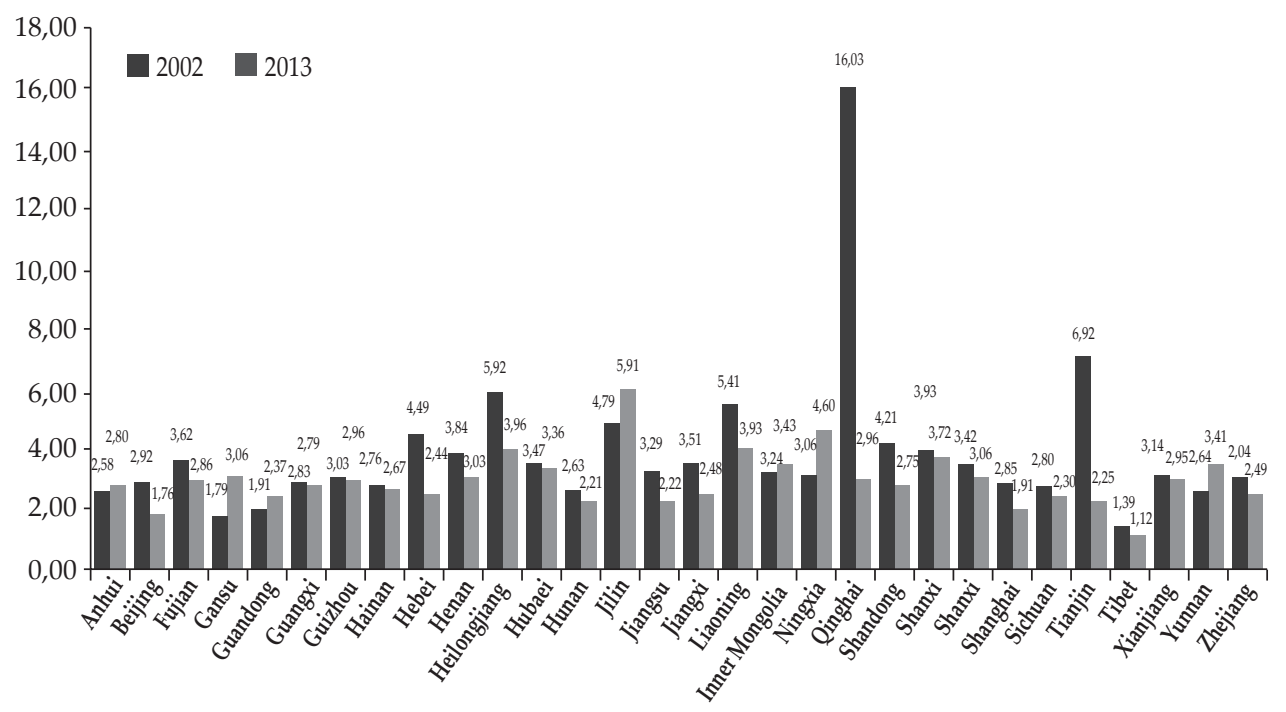


An additional issue is the role of other variables that may affect innovation. We control for all such variables, conditional on data availability. First economic development matters as it considered to be the main factor that influences innovation ability (Cheung and Lin, 2004). In a similar tone, Anokhin and Schulze (2009) argue that the level of social wealth influences enterprise innovation. Therefore, we use the real per capita gross domestic product (GDP) in constant 2000 currency units (GDP) to proxy for economic development.

Second is foreign direct investment $(F D I)$ as argued in the work of Wang and Kafouros (2009) and Kennel (2007). Following these studies, foreign capital disbursed to the regional GDP (ratio form) is used to measure FDI levels.

Finally, foreign trade is also a contributor to enterprise innovation. On the one hand, domestic enterprises can learn from foreign competitors and customers through their exports abroad and thus have an opportunity to increase innovation performance (Kokko, 1996; Salomon and Shaver, 2005). On the other hand, it is helpful for domestic enterprises to learn the technology and new business thinking of foreign enterprises by importing their advanced products. Thus, we include as a control variable the value of regional total imports and exports to the regional GDP, OPEN. The variables GDP, FDI, and OPEN are obtained from the China Statistical Yearbook.

\section{EMPIRICAL RESULTS}

$A$. Effects of government $R \mathcal{E} D$ expenditure on enterprise innovation

Of the independent variables GRD, COR, GDP, FDI, and OPEN, COR and FDI are exogenous (Paunov, 2016; Kennel, 2007). The variables GRD and GDP are endogenous because regional innovative ability can affect the level of economic development and R\&D expenditures to a certain extent (Anokhin and Schulze, 2009; Cin et al., 2017) and foreign trade could be correlated with the missing variables (Salomon and Shaver, 2005). To ensure maximum efficiency, instruments are proxied by lagged values of endogenous variables (as in Beck et al., 2000). The GMM regression estimates for the dependent variable NPA are displayed in Table 1 and the regional dummy variables are excluded from regression (1).

To start, Table 1 shows that GDP, FDI, and OPEN are statistically different from zero (and carry a positive sign) at the $5 \%$ level in most equations (columns (1) and (3) for GDP; all specifications for FDI; and columns (1), (2), and (4) for $O P E N)$, suggesting that higher real per capita GDP, foreign direct investment, and trade contribute to an increase in innovation. However, although the coefficient of GRD is positive in all equations, the coefficient is not statistically significant, meaning that $R \& D$ expenditure does not significantly increase the number of patent applications for enterprises in China. In other words, R\&D expenditure does not have the expected effect during the sample period. 
Table 1.

Effects of Government R\&D Expenditure on NPA

This table shows the effects of government $R \& D$ expenditure on the number of patent applications. The $t$-statistics are given in parentheses following each coefficient. Finally, ${ }^{*}$ and ${ }^{* *}$ indicate statistical significance at the $10 \%$ and $1 \%$ levels, respectively.

\begin{tabular}{|c|c|c|c|c|}
\hline & & & & \\
\hline & (1) & (2) & (3) & (4) \\
\hline$N P A_{t-1}$ & $0.097^{* *}$ & $0.217^{* *}$ & $0.619^{* *}$ & $0.524^{* *}$ \\
\hline & [5.319] & [6.024] & [3.165] & [3.461] \\
\hline GRD & 0.145 & 0.456 & 0.845 & 0.561 \\
\hline & [0.069] & [0.561] & [1.078] & [0.079] \\
\hline GDP & $0.461^{* *}$ & 0.461 & $0.231^{*}$ & 0.204 \\
\hline & [4.236] & [0.632] & [1.951] & [0.297] \\
\hline$F D I$ & $0.102^{* *}$ & $0.256^{* *}$ & $0.679^{* *}$ & $0.155^{* *}$ \\
\hline & [7.048] & [2.134] & [8.427] & [5.732] \\
\hline OPEN & $0.503^{* *}$ & $0.367^{* *}$ & 0.518 & $0.641^{* *}$ \\
\hline & [3.145] & [4.625] & [0.512] & [4.327] \\
\hline Eastern & & $0.561^{* *}$ & & \\
\hline & & [7.019] & & \\
\hline Central & & & $0.336^{* *}$ & \\
\hline & & & [6.942] & \\
\hline Western & & & & -0.167 \\
\hline & & & & [-1.642] \\
\hline Observations & 330 & 330 & 330 & 330 \\
\hline AR test (1) & 0.001 & 0.001 & 0.001 & 0.001 \\
\hline AR test (2) & 0.433 & 0.357 & 0.389 & 0.304 \\
\hline Instruments & 13 & 9 & 7 & 5 \\
\hline Hansen test & 0.348 & 0.409 & 0.309 & 0.385 \\
\hline
\end{tabular}

We next investigate the estimated results of three regional dummy variables. The variables Eastern and Central are statistically different from zero (at the 5\% level) and carry a positive sign in columns (2) and (3), respectively, which implies that the eastern and central regions of China have relatively higher quantities of patent applications. However, this is not the case for the western region, since the coefficient of Western is not significant in column (4).

The results for NPG as the dependent variable are shown in Table 2. We find the interesting result that GRD is positive and statistically significant at the 5\% level in all specifications, implying that larger R\&D expenditures are associated with higher NPG values. In comparison with Table 1, we provide evidence that GRD has a clearer impact on NPG than on NPA though both proxies for innovation output. 
Table 2.

\section{Effects of Government R\&D Expenditure on NPG}

This table shows the effects of government R\&D expenditure on the number of patents granted. The $t$-statistics are given in parentheses following each coefficient. Finally, ${ }^{* *}$ indicates statistical significance at the $1 \%$ level.

\begin{tabular}{|c|c|c|c|c|}
\hline & & & & \\
\hline & (1) & (2) & (3) & $(4)$ \\
\hline$N P G_{t-1}$ & $0.661^{* *}$ & $0.600^{* *}$ & $0.431^{* *}$ & $0.607^{* *}$ \\
\hline & [9.812] & [7.415] & [5.246] & [7.322] \\
\hline$G R D$ & $0.411^{* *}$ & $0.284^{* *}$ & $0.201^{* *}$ & $0.421^{\text {** }}$ \\
\hline & [6.154] & [5.364] & [2.197] & [7.459] \\
\hline GDP & $0.369^{* *}$ & $0.437^{* *}$ & $0.635^{* *}$ & $0.261^{* *}$ \\
\hline & [8.752] & [9.762] & [1.968] & [3.217] \\
\hline FDI & $0.206^{* *}$ & $0.261^{* *}$ & 0.403 & $0.654^{* *}$ \\
\hline & [4.513] & [7.149] & [1.351] & [4.988] \\
\hline OPEN & $0.154^{* *}$ & 0.199 ** & $0.361^{* *}$ & $0.451^{\text {** }}$ \\
\hline & [6.931] & [6.572] & [8.763] & [7.445] \\
\hline Eastern & & $0.134^{* *}$ & & \\
\hline & & [5.061] & & \\
\hline Central & & & $0.163^{* *}$ & \\
\hline & & & [2.661] & \\
\hline Western & & & & 0.125 \\
\hline & & & & [0.681] \\
\hline Observations & 330 & 330 & 330 & 330 \\
\hline ARtest (1) & 0.000 & 0.000 & 0.000 & 0.001 \\
\hline ARtest (2) & 0.534 & 0.315 & 0.315 & 0.335 \\
\hline Instruments & 17 & 11 & 9 & 7 \\
\hline Hansen test & 0.432 & 0.298 & 0.298 & 0.589 \\
\hline
\end{tabular}

As seen in Table 2, the estimated results of GDP, FDI, and OPEN are very similar to our earlier findings; the only exception is the variable FDI in column (3). Furthermore, the dummy variables Eastern and Central are still positive and statistically significant at conventional levels in columns (2) and (3), respectively, in Table 2. The regional effect of Western, however, is weaker in column (4) and statistically insignificant. As anticipated, these results are also in line with the view that the eastern and central areas exhibit higher degrees of economic development in China and also generate greater competition in enterprise innovative activity, leading to high levels of innovation performance.

We finally consider the effect of the autoregressive parameter. The lagged dependent variable statistically different from zero (at the 5\% level) and carries a positive sign in all columns in Tables 1 and 2 . The implication is that past levels of innovation performance are significantly associated with current levels of innovation output. In particular, provinces that experienced high levels of innovation performance in the past will continue to do so in the future. We also check whether there is autocorrelation in the error term and present the results in Tables 1 and 2. The Arellano-Bond test shows no evidence of autocorrelation and the Hansen test does not reject the null hypothesis that all the IVs are effective. The test results show that system GMM estimation is suitable for our empirical model. 
B. Effects of corruption and government RED expenditure on innovation

To further check the effect of corruption on innovation and determine whether bribery contributes to enterprises receiving R\&D funding, which then increases the possibility of innovation in China, we add COR and its interaction with GRD to model (3). The dependent variables NPA and NPG are displayed in Tables 3 and 4 , respectively.

Table 3.

Effects of Corruption and Government R\&D Expenditure on NPA

This table shows the effects of corruption and government R\&D expenditure on the number of patents applications. The $t$-statistics are given in parentheses following each coefficient. Finally, ${ }^{* *}$ indicates statistical significance at the $1 \%$ level.

\begin{tabular}{|c|c|c|c|c|}
\hline & & & & \\
\hline & (1) & (2) & (3) & (4) \\
\hline$N P A_{t-1}$ & $0.299 * *$ & $0.251^{* *}$ & $0.452^{* *}$ & $0.091^{* *}$ \\
\hline & {$[4.267]$} & [6.114] & [5.315] & [6.231] \\
\hline GRD & 0.101 & -0.413 & 0.061 & 0.462 \\
\hline & {$[1.108]$} & {$[-1.035]$} & [1.088] & [0.317] \\
\hline COR & $0.215^{* *}$ & $0.651^{* *}$ & $0.464^{* *}$ & 0.463 \\
\hline & {$[4.532]$} & [3.564] & [3.524] & [1.549] \\
\hline$G R D^{*} C O R$ & $0.314^{* *}$ & $0.415^{* *}$ & $0.641^{* *}$ & 0.615 \\
\hline & [6.195] & [5.615] & [9.451] & [0.881] \\
\hline GDP & $0.512^{* *}$ & $0.326^{* *}$ & $0.752^{* *}$ & $0.319^{* *}$ \\
\hline & [7.411] & [2.981] & [6.422] & [6.495] \\
\hline FDI & $0.294^{* *}$ & $0.274^{* *}$ & $0.543^{* *}$ & $0.471^{* *}$ \\
\hline & {$[8.463]$} & [2.343] & [3.545] & [3.251] \\
\hline OPRN & $0.381^{* *}$ & $0.213^{* *}$ & 0.066 & $0.267^{* *}$ \\
\hline & [7.125] & [6.446] & [1.293] & [6.224] \\
\hline Eastern & & $0.209^{* *}$ & & \\
\hline & & [5.881] & & \\
\hline Eastern*COR & & $0.431^{* *}$ & & \\
\hline & & [7.049] & & \\
\hline Central & & & $0.383^{* *}$ & \\
\hline & & & [5.141] & \\
\hline Central*COR & & & $0.251^{* *}$ & \\
\hline & & & [8.572] & \\
\hline Western & & & & -0.672 \\
\hline & & & & {$[-0.243]$} \\
\hline Western*COR & & & & 0.145 \\
\hline & & & & [0.459] \\
\hline Observations & 328 & 328 & 328 & 328 \\
\hline ARtest (1) & 0.001 & 0.001 & 0.001 & 0.001 \\
\hline ARtest (2) & 0.612 & 0.733 & 0.438 & 0.438 \\
\hline Instruments & 17 & 11 & 9 & 7 \\
\hline Hansen test & 0.233 & 0.409 & 0.654 & 0.329 \\
\hline
\end{tabular}

For Table 3, the effect of GRD on NPA is still statistically zero in columns (1) to (4); however, the variable COR has a positive impact on NPA and is statistically different from zero in columns (1) to (3) but statistically insignificant in column (4). It is important to note that, because China has no perfect market mechanism, the government usually plays a critical role in intervening in economic activities. 
Under such circumstances, most enterprises tend to offer bribes to government officials to avoid political risk, which leads to rampant official corruption and low institution quality. Therefore, bribery becomes a way to reduce administrative intervention, avoid bureaucratic red tape, and facilitate enterprise innovation in China.

As argued earlier, considering the interaction effects of R\&D spending and bribery, because these variables can interact in determining innovative performance across provinces, is important. We see that all the interaction effects $G R D^{*} C O R$ are positive and statistically different from zero (see column (1) of Table $3)$. Most of the evidence suggests that the effect of R\&D expenditure on NPA is influenced by the level of corruption and that corruption helps increase the effect of $R \& D$ expenditure in China. That is because bribery can reduce administrative intervention, promote administrative efficiency, and help enterprises receive government innovation subsidies. However, the cost of bribery is so high that enterprise innovation ability cannot fundamentally improve and, so, the effect of GRD on NPA is still statistically insignificant.

We also add regional dummy variables and their interaction variables with COR, as shown in columns (2) to (4) in Table 3. Consistent with earlier findings, both the coefficients of Eastern and Central and their interaction terms with COR appears to be statistically significant, with a positive impacts on NPA, whereas the coefficient in regression (4) is not statistically different from zero, implying that the level of innovation in the western area is low compared to the eastern and central areas. Additionally, concerning the other explanatory variables, we find their effects to also be similar to our earlier findings.

Table 4.

Effects of Corruption and Government R\&D Expenditure on NPG

This table shows the effects of corruption and government R\&D expenditure on the number of patents granted. The $t$-statistics are given in parentheses following each coefficient. Finally, ${ }^{* *}$ indicates statistical significance at the $1 \%$ level.

\begin{tabular}{lcccc}
\hline & \multicolumn{4}{c}{$N P G$} \\
\cline { 2 - 5 } & $\mathbf{( 1 )}$ & $\mathbf{( 2 )}$ & $\mathbf{( 3 )}$ & $\mathbf{( 4 )}$ \\
\hline$N P G_{t-1}$ & $0.301^{* *}$ & $0.211^{* *}$ & $0.676^{* *}$ & $0.443^{* *}$ \\
\multirow{3}{*}{$G R D$} & {$[3.009]$} & {$[5.989]$} & {$[4.556]$} & {$[6.765]$} \\
& $0.434^{* *}$ & $0.233^{* *}$ & $0.212^{* *}$ & $0.334^{* *}$ \\
COR & {$[6.009]$} & {$[5.123]$} & {$[3.093]$} & {$[6.162]$} \\
& $0.203^{* *}$ & $0.155^{* *}$ & $0.232^{* *}$ & 0.054 \\
GRD $C O R$ & {$[4.122]$} & {$[2.099]$} & {$[4.097]$} & {$[1.098]$} \\
& $0.208^{* *}$ & $0.335^{* *}$ & $0.509^{* *}$ & 0.032 \\
GDP & {$[4.554]$} & {$[4.098]$} & {$[11.344]$} & {$[0.087]$} \\
& $0.403^{* *}$ & $0.229^{*}$ & $0.445^{* *}$ & $0.228^{* *}$ \\
FDI & {$[2.088]$} & {$[1.734]$} & {$[7.246]$} & {$[5.232]$} \\
& $0.343^{* *}$ & $0.209^{* *}$ & $0.554^{* *}$ & $0.023^{* *}$ \\
OPEN & {$[10.340]$} & {$[2.121]$} & {$[2.354]$} & {$[2.342]$} \\
& $0.412^{* *}$ & $0.113^{* *}$ & 0.032 & $0.229^{* *}$ \\
\hline
\end{tabular}


Table 4.

Effects of Corruption and Government R\&D Expenditure on NPG (Continued)

\begin{tabular}{|c|c|c|c|c|}
\hline & \multicolumn{4}{|c|}{$N P G$} \\
\hline & (1) & (2) & (3) & (4) \\
\hline \multirow[t]{2}{*}{ Eastern } & & $0.105^{* *}$ & & \\
\hline & & [5.099] & & \\
\hline \multirow[t]{2}{*}{ Eastern*COR } & & $0.512^{* *}$ & & \\
\hline & & {$[6.034]$} & & \\
\hline \multirow[t]{2}{*}{ Central } & & & $0.023^{* *}$ & \\
\hline & & & [2.656] & \\
\hline \multirow[t]{2}{*}{ Central $^{*} \mathrm{COR}$} & & & $0.433^{* *}$ & \\
\hline & & & [7.056] & \\
\hline \multirow[t]{2}{*}{ Western } & & & & -0.746 \\
\hline & & & & {$[-0.334]$} \\
\hline \multirow[t]{2}{*}{ Western*COR } & & & & 0.189 \\
\hline & & & & {$[0.665]$} \\
\hline Observations & 328 & 328 & 328 & 328 \\
\hline ARtest (1) & 0.001 & 0.001 & 0.001 & 0.001 \\
\hline ARtest (2) & 0.665 & 0.657 & 0.387 & 0.558 \\
\hline Instruments & 19 & 13 & 11 & 7 \\
\hline Hansen test & 0.201 & 0.405 & 0.765 & 0.746 \\
\hline
\end{tabular}

Table 4 shows the GMM regression estimates for dependent variable NPG. These estimates are consistent with evidence reported in Table 3, apart from the variable $G R D$, which appears to be positive and statistically significant at least at the $5 \%$ level in all columns. Generally, our results provide clear findings on the relationships between R\&D expenditure, corruption, and enterprise innovation. In other words, enterprises establish relationships with government officials through bribery to obtain R\&D funding support, reduce political resistance against their projects, and speed up the process of patent applications and authorization.

C. Extended specification: Effects of corruption on the ratio of the number of patents granted to the number of patent applications

To confirm robustness, we again examine the influence of GRD, COR, and the interaction term $G R D^{*} C O R$ on the ratio of the number of patents granted to the number of patent applications (RGA). Given that Hirshleifer et al. (2012) argues for $R G A$ being a suitable indicator to proxy for the effectiveness of innovative performance, we change the explained variable to $R G A$, with the results reported in Table 5. 
Table 5.

Effect of Corruption on $R G A$

This table shows the effects of corruption on the ratio of the number of patents granted to the number of patent applications (RGA). The $t$-statistics are given in parentheses following each coefficient. Finally, ${ }^{* *}$ indicates statistical significance at the $1 \%$ level.

\begin{tabular}{|c|c|c|c|c|}
\hline & \multicolumn{4}{|c|}{$R G A$} \\
\hline & (1) & (2) & (3) & (4) \\
\hline \multirow[t]{2}{*}{$R G A_{t-1}$} & $0.103^{* *}$ & $0.255^{* *}$ & $0.344^{* *}$ & $0.552^{* *}$ \\
\hline & {$[2.094]$} & {$[4.088]$} & [4.099] & [6.003] \\
\hline \multirow[t]{2}{*}{ GRD } & $2.093^{* *}$ & $1.143^{* *}$ & $1.654^{* *}$ & 0.223 \\
\hline & {$[5.088]$} & {$[3.556]$} & [3.095] & [1.110] \\
\hline \multirow[t]{2}{*}{ COR } & $0.332^{* *}$ & $0.544^{* *}$ & $0.884^{* *}$ & $0.328^{* *}$ \\
\hline & {$[5.940]$} & [6.093] & {$[4.034]$} & [6.934] \\
\hline \multirow[t]{2}{*}{$G R D^{*} C O R$} & $0.121^{* *}$ & $0.133^{* *}$ & $0.154^{* *}$ & $0.664^{* *}$ \\
\hline & [5.102] & {$[6.202]$} & {$[4.746]$} & [3.956] \\
\hline \multirow[t]{2}{*}{ GDP } & $0.340^{* *}$ & $0.335^{* *}$ & $0.774^{* *}$ & $0.176^{* *}$ \\
\hline & {$[3.930]$} & {$[3.454]$} & [3.493] & [3.948] \\
\hline \multirow[t]{2}{*}{ FDI } & $0.203^{* *}$ & $0.745^{* *}$ & $0.229^{* *}$ & $0.847^{* *}$ \\
\hline & {$[4.066]$} & [3.009] & [3.087] & [2.887] \\
\hline \multirow[t]{2}{*}{ OPEN } & $0.103^{* *}$ & $0.098^{* *}$ & $0.224^{* *}$ & $0.554^{* *}$ \\
\hline & {$[2.034]$} & {$[4.835]$} & [3.098] & [6.093] \\
\hline \multirow[t]{2}{*}{ Eastern } & & $0.887^{* *}$ & & \\
\hline & & {$[2.933]$} & & \\
\hline \multirow[t]{2}{*}{ Eastern*COR } & & $0.403^{* *}$ & & \\
\hline & & [5.098] & & \\
\hline \multirow[t]{2}{*}{ Central } & & & $0.233^{* *}$ & \\
\hline & & & {$[6.855]$} & \\
\hline \multirow[t]{2}{*}{ Central ${ }^{*} \mathrm{COR}$} & & & $0.233^{* *}$ & \\
\hline & & & [6.855] & \\
\hline \multirow[t]{2}{*}{ Western } & & & & 0.103 \\
\hline & & & & {$[0.235]$} \\
\hline \multirow[t]{2}{*}{ Western*COR } & & & & -0.002 \\
\hline & & & & {$[-0.934]$} \\
\hline Observations & 328 & 328 & 328 & 328 \\
\hline ARtest (1) & 0.001 & 0.001 & 0.001 & 0.001 \\
\hline ARtest (2) & 0.211 & 0.398 & 0.455 & 0.283 \\
\hline Instruments & 23 & 15 & 13 & 9 \\
\hline Hansen test & 0.645 & 0.553 & 0.932 & 0.847 \\
\hline
\end{tabular}

As before, the adjustment of the dependent variable does not substantially influence our findings. Here, GRD, COR, and the interaction term GRD*COR still present statistically significant positive effects on $R G A$ in most cases; the results continue to support our earlier analysis. Enterprises do establish opaque relationships with government officials through bribery and try to obtain R\&D funding from the government for innovation. Overall, the impacts of the control variables on $R G A$ in Table 5 are mostly consistent with our earlier models, as our evidence makes clear. 


\section{CONCLUSIONS}

This paper integrates corruption into the estimation of how $R \& D$ expenditure affects enterprise innovation for Chinese provinces. We find that $R \& D$ expenditure presents an unobvious influence on the number of patent applications but does lead to greater numbers of patents granted. Though the finding seems controversial, it becomes more interesting after we add corruption and its interaction term with R\&D expenditure to the model. In particular, we find that the incidence of corruption and the interaction term with R\&D expenditure mostly impact innovation positively. The implication is that corruption can contribute to connecting together enterprises and government, thus speeding up patent applications and authorizations granted.

The findings of this study are consistent with the predictions of previous studies, indicating that corruption plays an important role in facilitating and easing the operation of administrative procedures for examination and approval, especially in developing countries. The current study confirms these phenomena in China, which is also an economy in transition, with lower institution quality and administrative transparency.

Although this study demonstrates that corruption is positively related to the numbers of patent applications and patents granted in China, it does not mean that corruption itself makes a positive contribution. Institutional deficiencies such as red tape in bureaucracy, lack of administrative transparency, information asymmetry, and so forth create opportunities for corruption as a shortcut to overcome these constraints in government and administrative procedures. In other words, the lower the quality of the institutional framework, the higher the country's level of corruption. When institutions are relatively efficient, observed corruption is likely to be associated with relatively lower functionality. Conversely, in countries with low-quality institutions (e.g., excessively burdensome regulations), corruption can lead to relatively more functionality. In fact, corruption is both a major cause and a result of low-quality institutions. Therefore, although the findings of this study show that corruption is the lubricant of enterprise innovation, it is due to the deficiency in institutional quality and leads to the replacement of formal and legal institutions with informal and corrupt "rules of the game." The proposition that corruption can improve efficiency is expected to be hold only when the costs of institutional deficiency exceed the benefits of corruption under ill-governed regimes.

In particular, over the past five years, a series of anticorruption measures have been adopted by the Chinese government to improve legal and regulatory systems; an anticorruption campaign is thus being consolidated and continues to build. This example reflects the structural reforms in institutional quality in China, even though the corrupt ties between business and government are hard to remove in the short term, as shown by our findings. Once institutional quality is improved, the moderating effect of corruption on the relationship between R\&D expenditure and enterprise innovation is expected to have a lesser impact.

Our findings lead to important policy recommendations since policymakers and enterprises need to investigate more closely the causes of R\&D expenditure across provinces to promote growth in innovative activity. Although anticorruption activities in China might not be favorable to enterprise innovation at present, since 
they could destroy the original ties between governments and business persons and thus reduce the administrative efficiency of local and central governments, this period of economic and institutional reforms is a painful stage for China.

\section{REFERENCES}

Acemoglu, D. and Verdier, T. (1998). Property Rights, Corruption and the Allocation of Talent: A General Equilibrium Approach. The Economic Journal, 108, 1381-1403.

Ahlin, C. and Bose, P. (2007). Bribery, Inefficiency and Bureaucratic Delay. Journal of Development Economics, 84, 465-486.

Aidis, R., Estrin, S. and Mickiewicz, T. (2008). Institutions and Entrepreneurship Development in Russia: A Comparative Perspective. Journal of Business Venturing, 23, 656-672.

Aidt, T. and Dutta, J. (2008). Policy Compromises: Corruption and Regulation in a Democracy. Economics and Politics, 20, 335-360.

Alesina, A., Ardagna, S., Nicoletti, G. and Schiantarelli, F. (2005). Regulation and Investment. Journal of the European Economic Association, 3, 791-825.

Amir, R. and Burr, C. (2015). Corruption and Socially Optimal Entry. Journal of Public Economics, 123, 30-41.

Anderson, T. W. and Hsiao, C. (1981). Estimation of Dynamic Models with Error Components. Journal of the American Statistical Association, 76, 598-606.

Anokhin, S. and Schulze, W. (2009). Entrepreneurship, Innovation and Corruption. Journal of Business Venturing, 24, 465-476.

Arellano, M. (2003a). Panel Data Econometrics. Oxford University Press.

Arellano, M. (2003b). Modeling Optimal Instrumental Variables for Dynamic Panel Data Models. Working Paper 0310, Centro de Estudios Monetariosy Financieros, Madrid.

Arellano, M. and Bond, S. (1991). Some Tests of Specification for Panel Data: Monte Carlo Evidence and an Application to Employment Equations. The Review of Economic Studies, 58, 277-297.

Arellano, M. and Bover, O. (1995). Another Look at The Instrumental Variable Estimation of Error-components Models. Journal of Econometrics, 68, 29-51.

Argyres, N. and Brain, S. (2004). R\&D, Organization Structure and the Development of Corporate Technological Knowledge. Strategic Management Review, 25, 929958.

Baker, C. I., Peli, E., Knouf, N. and Kanwisher, N. G. (2005). Reorganization of Visual Processing in Macular Degeneration. Journal of Neuroscience, 25, 614-618. Baltagi, B. H. (2008). Econometric Analysis of Panel Data. Wiley Press.

Barbosa, N., Faria, A. P. and Eiriz, V. (2014). Industry and Firm-specific Factors of Innovation Novelty. Industrial and Corporate Change, 23, 865-902.

Baumol, W. J. (1990). Entrepreneurship: Productive, Unproductive, and Destructive. Journal of Political Economy, 98, 893-921.

Beck, T., Levine, R. and Loayza, N. (2000). Finance and the Sources of Growth. Journal of Financial Economics, 58, 261-300. 
Blackburn, K. and Forgues-Puccio, G. F. (2009). Why is Corruption Less Harmful in Some Countries than in Others? Journal of Economic Behavior and Organization, 72, 797-810.

Blundell, R. and Bond, S. (1998). Initial Conditions and Moment Restrictions in Dynamic Panel Data Models. Journal of Econometrics, 87, 115-143.

Boeing, P. (2016). The Allocation and Effectiveness of China's R\&D Subsidies Evidence from Listed Firms. Research Policy, 45, 1774-1789.

Bronzini, R. and Piselli, P. (2016). The Impact of R\&D Subsidies on Firm Innovation. Research Policy, 45, 442-457.

Cheung, K. and Lin, P. (2004). Spillover Effects of FDI on Innovation in China: Evidence from The Provincial Data. China Economic Review, 15, 25-44.

Choi J. and Lee J. (2017). Repairing the R\&D Market Failure: Public R\&D Subsidy and the Composition of Private R\&D. Research Policy, 46, 1465-1478.

Cin B. C., Kim Y. J. and Vonortas N. S. (2017). The Impact of Public R\&D Subsidy on Small Firm Productivity: Evidence from Korean SMEs. Small Business Economics, 48, 345-360.

Cropper, M. and Oates, W. (1992). Environmental Economics: A Survey. Journal of Economic Literature, 30, 675-740.

David, P., Hall, B. and Toole, A. (2000). Is Public R\&D a Complement or Substitute for Private R\&D? A Review of the Econometric Evidence. Research Policy, 29, 497-529.

Delong, J. B. and Lawrence, H. S. (1991). Equipment Investment and Economic Growth. Quarterly Journal of Economics, 106, 445-502.

De Rosa, D., Gooroochurn, N. and Gorg, H. (2010). Corruption and Productivity: Firm-level Evidence from the BEEPS Survey. Policy Research Working Paper Series, 5348, The World Bank.

Desyllas, P. and Hughes, A. (2010). Do High Technology Acquirers Become More Innovative? Research Policy, 39, 1105-1121.

Dimos, C. and Pugh, G. (2016). The Effectiveness of R\&D Subsidies: A Metaregression Analysis of the Evaluation Literature. Research Policy, 45, 797-815.

Dirienzo, C. and Das, J. (2014). Innovation and Role of Corruption and Diversity: A Cross-country Study. International Journal of Cross Cultural Management, 27, 1-22.

Diamond, A. M. (1999). Does Federal Funding 'Crowd in' Private Funding of Science. Contemporary Economic Policy, 17, 423-431.

Dong, B. and Torgler, B. (2013) Causes of Corruption: Evidence from China. China Economic Review, 26, 152-169.

Dreher, A. and Gassebner, M. (2013) Greasing the Wheels? The Impact of Regulations and Corruption on Firm Entry. Public Choice, 155, 413-432.

Dushnitsky, G. and Lenox, M. J. (2006). When Does Corporate Venture Capital Investment Create Firm Value? Journal of Business Venturing, 21, 753-772.

Fey M. (2008). Rent-seeking Contests with Incomplete Information. Public Choice, $135,225-236$.

Fisman, R. and Svensson, J. (2007). Are Corruption and Taxation Really Harmful to Growth? Firm Level Evidence. Journal of Development Economics, 83, 63-75. 
Gao Y. (2011). Government Intervention, Perceived Benefit, and Bribery of Firms in Transitional China. Journal of Business Ethics, 2011, 104, 175-184.

Glaeser, E. and Saks, R. (2006). Corruption in America. Journal of Public Economics, 90, 1053-1072.

Goedhuys, M., Mohnen, P. and Taha, T. (2016). Corruption, Innovation and Firm Growth: Firm-level Evidence from Egypt and Tunisia. Eurasian Business Review, 6, 299-322.

Griliches, Z. (1986). Productivity, Research-and-development, and Basic Research at the Firm Level in the 1970s. American Economic Review, 76, 141-154.

Guisado-González M., González-Blanco J., Coca-Pérez J. L. and Guisado-Tato, M. (2018). Assessing the Relationship between R\&D Subsidy, R\&D Cooperation and Absorptive Capacity: An Investigation on the Manufacturing Spanish Case. The Journal of Technology Transfer, 43, 1647-1666.

Guo, D., Guo, Y. and Jiang, K. (2016). Government-subsidized R\&D and Firm Innovation: Evidence from China. Research Policy, 45, 1129-1144.

Hall, B. H. and Lerner, J. (2010). The Financing of R\&D and Innovation. in Hall, B. H. and Rosenberg, N. (ed.), Handbook of the Economics of Innovation, Amsterdam: North Holland, pp. 609-639.

Hirshleifer, D., Low, A. and Teoh, S. H. (2012). Are Overconfident CEOs Better Innovators? The Journal of Finance, 67, 1457-1498.

Hsiao, C. (2003). Analysis of Panel Data. Cambridge University Press.

Kennel, J. S. (2007). Foreign Direct Investment and Local Linkages: An Empirical Investigation. Management International Review, 47, 51-77.

Kokko, A. (1996). Productivity Spillovers from Competition between Local Firms and Foreign Affiliates. Journal of International Development, 8, 517-530.

Krueger, A. (1974). The Political Economy of the Rent-seeking Society. American Economic Review, 64, 291-303.

Le T., Jaffe A. B. (2017). The Impact of R\&D Subsidy on Innovation: Evidence from New Zealand Firms. Economics of Innovation and New Technology, 26, 429-452.

Leff, N. H. (1964). Economic Development through Bureaucratic Corruption. The American Behavioral Scientist, 8, 8-14.

Lerner, J. and Wulf, J. (2007). Innovation and Incentives: Evidence From Corporate R\&D. Review of Economics and Statistics, 89, 634-644.

Lin, C., Lin, P., Song, F. and Li, C. (2011). Managerial Incentives, CEO Characteristics and Corporate Innovation in China's Private Sector. Journal of Comparative Economics, 39, 176-190.

Li, H., Meng, L., Wang, Q. and Zhou, L. (2008). Political Connections, Financing and Firm Performance: Evidence from Chinese Private Firms. Journal of Development Economics, 87, 283-299.

Matyas, L. and Sevestre, P. (2008). The Econometrics of Panel Data. Springer.

Murphy, K., Shleifer, A. and Vishny, R. (1991). The Allocation of Talent: Implications for Growth. Quarterly Journal of Economics, 106, 503-530.

Nelson, R. (1971). Simple Economics of Basic Scientific Research. The Journal of Political Economy, 67, 725-736.

Nelson, R. and Winter, S. G. (1982). The Schumpeterian Tradeoff Revisited. The American Economic Review, 72, 114-132. 
Paunov, C (2016). Corruption's Asymmetric Impacts on Firm Innovation. Journal of Development Economics, 118, 216-231.

Qian, Y. and $\mathrm{Xu}, \mathrm{C}$. (1998). Innovation and Bureaucracy under Soft and Hard Budget Constraints. The Review of Economic Studies, 65, 151-164.

Rodriguez, P., Siegel, D. S., Hillman, A. and Eden, L. (2006). Three Lenses on the Multinational Enterprise: Politics, Corruption, and Corporate Social Responsibility. International Business Studies, 37, 733-746.

Romer, P. M. (1990). Endogenous Technological Change. The Journal of Political Economy, 98, 71-102.

Rose-Ackerman, S. (2001). Trust, Honesty, and Corruption: Reflection of the Statebuilding Process. European Journal of Sociology, 42, 526-570.

Salomon, R. M. and Shaver, J. M. (2005). Learning by Exporting: New Insights from Examining Firm Innovation. Journal of Economics \& Management Strategy, 14, 431-460.

Schumpeter, J. A. (1934). The Theory of Economic Development: An Inquiry into Profits, Capital, Interest and the Business Cycle. Transaction Publishers.

Shleifer, A. and Vishny, R. W. (1994). Politicians and Firms. The Quarterly Journal of Economics, 109, 995-1025.

Shi, Y. and Rao, Y. (2010). China's Research Culture. Science, 329, 1128-1128.

Svensson, J. (2003). Who Must Pay Bribes and How Much? Evidence from a Cross Section of Firms. Quarterly Journal of Economics, 118, 207-230.

Tanzi, V. (1998). Corruption around the World: Causes, Consequences, Scope and Cure. IMF Staff Papers, 45, 559-594.

Ueda, M. (2004). Banks versus Venture Capita: Project Evaluation, Screening, and Expropriation. The Journal of Finance, 59, 601-621.

Uhlenbruck, K., Rodriguez, P., Doh, J. and Eden, L. (2006). The Impact of Corruption on Entry Strategy: Evidence from Telecommunication Projects in Emerging Economies. Organization Science, 17, 402-414.

Wallsten, S. J. (2000). The Effects of Government-industry R\&D Programs on Private R\&D: the Case of the Small Business Innovation Research Program. RAND Journal of Economics, 31, 82-100.

Vicente, J., Borrego, C., Forcadell, F. and Galan, J. (2014). Assessing the Effect of Public Subsidies on Firm R\&D Investment: A Survey. Journal of Economic Surveys, 28, 36-67.

Waldemar, F. (2012). New Products and Corruption: Evidence from Indian Firms. The Developing Economies, 50, 268-284.

Wang, C. and Kafouros, M. I. (2009). What Factors Determine Innovation Performance in Emerging Economies? Evidence from China. International Business Review, 18, 606-616.

Williams, C. C., Martinez-Perez, A. and Kedir, A. (2016). Does Bribery Have a Negative Impact on Firm Performance? A Firm-level Analysis across 132 Developing Countries. International Journal of Entrepreneurial Behavior $\mathcal{E}$ Research, 22, 398-415.

Yeh, Y., Shu, P. and Chiu, S. (2013). Political Connections, Corporate Governance and Preferential Bank Loans. Pacific-Basin Finance Journal, 21, 1079-1101. 